\title{
PLANT DIVERSITY IN PARI ISLAND MARINE RESEARCH STATION OF INDONESIA SOUTH CHINA SEA: RARE PLANTS AND THEIR CONSERVATION
}

\author{
Sukristiono Sukardjo ${ }^{* 1}$ and Rianta Pratiwi ${ }^{2}$ \\ ${ }^{1}$ Present addres: Jln. Rawasari no.45. Bojong Pamoyanan, Bogor. Indonesia \\ ${ }^{2}$ Research Centre For Oceanography, Indonesian Institute of Sciences, Jl. Pasir Putih 1 Ancol Timur, \\ Jakarta 1430, Indonesia. \\ *Corresponding author: s_sukardjo@yahoo.com \\ Acknowledge: 21 June $2016 \quad$ Revise: 6 Oct $2016 \quad$ Accepted: 23 Nov 2016
}

\begin{abstract}
The zones surrounding Seribu Islands Marine National Park (SMNP) are the sites of many conflicts between SMNP managers and local populations. The Pari Island represents a buffer zone of the SMNP, and their peoples have authority to utilize the island as the inalienable village lands. The flora of the island was re-enumerated in 2005 for their rare status of species present and may be considered as the entity for IBSAP (Indonesia Bio-diversity Strategy and Action Plans) 2003-2020. A 2-times check list inventory (2001 and 2005) of the island documented 174 rare plants or the biodiversity status of the small island. A checklist of 174 rare plants in the Pari Island can be used to support management purposes of SMNP. Most of the rare plants have low local density and low frequency of occurrence of spatial distributional range, and have been used to characterize rarity (A-D). A brief comment on rare plants is described and discussed in the context of the biological diversity of the island.
\end{abstract}

Keywords: Botanical Exploration, Edible plants, Rare and Endangered Species, Conservation, Small Island, Indonesia.

\section{INTRODUCTION}

Indonesia is part of the plant geographical unit known as Malesia [59] [60] [27]. Malesia, comprising the political states of Indonesia, Malaysia, Brunei Darussalam, the Philippines, Singapore and Papua New Guinea (PNG), contains the largest areas of rainforest in the Old World and supports an incompletely know but diverse Angiosperm flora in excess of 40,000 species [71]. The area covers more than 3 million square kilometres and an elevation range from sea-level to $5000 \mathrm{~m}$, with a wide range of vegetation types and habitats covering extreme ever-wet to dry monsoon conditions, and from rich well drained to poor podzolic soils.

Indonesia is an archipelago state consisting of almost 17,504 islands with a coastline totalling some $96,181 \mathrm{~km}$, its territory made up at least as much of sea as it is of land. Indonesia covers only $1.3 \%$ of the Earth's surface, yet it harbours $10 \%$ of all flowering plants [27]. The country is floristically rich and characterized by many interesting ecosystems and habitats; and it is one of the 17 plant diversity richest countries in the world [3] [35]
[36]. The richness can, in part, be attributed to the fact that Indonesia spans two major biogeographical realms, Indo-Malaya and Australasia and can be divided into seven distinct bio-geographical regions, viz. (1) Sumatra and offshore islands, (2) Java and Bali, (3) Sulawesi, and offshore islands including Sula, (4) Kalimantan, including the Natuna and Anambas islands, (5) Nusa Tenggara, (6) Maluku, and (7) Irian Jaya, including the Kai and Aru islands [59] [62]. Also, the 17,508 islands of the archipelago support a wide range and variety of natural communities from lowland rain-forest and mangroves to savannas grassland, swamp forests and limestone hill vegetation to montane forests, alpine meadows and snow-topped mountains [65] [64] [63] [27] [35]; and the forested ecosystem of Indonesia is unique with a diverse tropical flora and high proportion of endemic species [65]. The country's marine and coastal assets, and fauna and flora are outstanding [27] [10]. Moreover, the plant life of small islands, which are in abundance in Indonesia, includes significant vegetation types (e.g., coral vegetation-strand flora), although these have received little descriptive attention in the literatures [55] [65]. Also, these natural resources 
are increasingly under threat from human activities such as tourism and resort and other development.

Seribu Island Marine National Park (SMNP: 107,489 ha) along with their buffer zone areas has been established by Ministry of Forestry on June 13, 2002 [43]. Consequently, the plant and/or marine species biota and their usage (e.g., ornamentals, edible food and medicine species) by the people in the buffer zone areas e.g., Pari Island plays crucially in managing the zones and their environment for sustaining the SMNP [52] [45] [49].

The botanical investigations in the Pari Island have mainly focused on vegetation and successional processes in relation to forced or natural changes in environmental parameters [55]. For conservation biologists, the study of the distribution and abundance of organisms acquires a special meaning. We particularly interested in the rare species, those who's scarcity or restricted range makes them more prone to extinction [58] [59]. Although collections of plants have been made in the Pari Island from 1984, the present study enumerated in 2005, and represent a part of the long term program on the Botanical Exploration in Small Islands of the SMNP. The importance of studying rare species has been recognized, few papers have dealt with rarity and its ecological correlates. The study of rarity is a central concern in modern conservation biology. However, rarity is not the only factor promoting extinction in small island.

First publication on the flora of Pari Island was annotated lists of plants occurring in the island [55]. Interest in species numbers are continued up to 2007 (Table 1). Interest was again revised by the investigation of small island biogeography and coastal species [49]. The figures were presented as one of the few botanical examples in the pioneer works in the small island and/or coral island in Indonesia in the line of implementation of Indonesian Biodiversity Strategy and Action Plan 2003-2020 (IBSAB 2003-2020) [10], and Law No.27/2007 on Coastal Zone and Small Islands Management. IBSAB is fundamental guide for the goverment and/or stake holder to implement biodiversity programe in practise.

Upon the suggestion of IBSAP 20032020 [10], and National Strategy for Mangrove Ecosystem Management in Indonesia 2006, and after revisiting the Pari Island after 20 years (in 2005), have been reported below an account of the distribution and status of the rare plants in Pari Island, although for many species distribution records and status assessments are preliminary. The present contribution may be regarded as a supplement to my works on 19841987 [55]. Some of the voucher specimen have been documented without field noted data or loose of information. The present paper also represent as rediscovery to flora of Java [7].

Table 1. Lists of rare plants occurring Pari Island. The nomenclatures follow [7] and for fern follows [8].

Introduce and ornament plant considered only for Indonesian Biodiversity Stategy and Action Plans.

R: rare species; Vr: Very rare species: ?: become common.

Rarity categories: A: species with local density (N) $>10$ and frequency of occurrence $(\mathrm{F})$ $<10 \%$; B: species

with $\mathrm{N}>10$ and $\mathrm{F}>10 \%$; $\mathrm{C}$ : species with $\mathrm{N}<10$ and $\mathrm{F}<10 \%$; D: species with $\mathrm{N}<10$ and $\mathrm{F}>10 \%$. 


\begin{tabular}{|c|c|c|c|c|c|c|}
\hline Family and Species & $\begin{array}{l}2005 \\
\text { (unpublish } \\
\text { documentation } \\
\text { of field notes) }\end{array}$ & $\begin{array}{l}\text { 2007(unpublish } \\
\text { documentation } \\
\text { of field notes) }\end{array}$ & $\mathbf{N}$ & $\begin{array}{l}\mathbf{F} \\
(\%)\end{array}$ & Rarity & Remarks \\
\hline \multicolumn{7}{|l|}{ I. GYMNOSPERMAE (1 family) } \\
\hline \multicolumn{7}{|l|}{ 1. CASUARINACEAE (1/1) } \\
\hline 1. Casuarina equisetifolia $\mathrm{L}$ & $\mathrm{R}$ & $\mathrm{R}$ & 7 & 7.50 & $\mathrm{C}$ & Indigenous tree \\
\hline \multicolumn{7}{|l|}{$\begin{array}{l}\text { II. MONOCOTYLEDONEAE (8 } \\
\text { families) } \\
\text { 1. AMARYLIDACEAE (1/1) }\end{array}$} \\
\hline 1. Crinum asiaticum $\mathrm{L}$. & $\mathrm{R}$ & $\mathrm{Vr}$ & 5 & 7.50 & $\mathrm{C}$ & Indigeous herb \\
\hline \multicolumn{7}{|l|}{ 2. ARACEAE 4/4)) } \\
\hline 1. Alocasia sp. & $\mathrm{R}$ & $\mathrm{R}$ & $\begin{array}{l}1 \\
4\end{array}$ & 7.50 & A & Indigenous herb \\
\hline 2. Amorphophalus sp. & $\mathrm{R}$ & $\mathrm{R}$ & $\begin{array}{l}1 \\
0\end{array}$ & 7.50 & A & Indigenous herb \\
\hline 3. Colocasia esculenta (L.) Schott & $\mathrm{R}$ & $\mathrm{R}$ & $\begin{array}{l}1 \\
4\end{array}$ & $\begin{array}{l}12.5 \\
0\end{array}$ & B & $\begin{array}{l}\text { Introduced herb, } \\
\text { cultivated }\end{array}$ \\
\hline 4. Cyrtosperma sp. & $\mathrm{R}$ & $\mathrm{Vr}$ & 5 & 7.50 & $\mathrm{C}$ & Indigenous herb \\
\hline \multicolumn{7}{|l|}{ 3. ARECACEAE (2/2) } \\
\hline 1. Areca catechu $\mathrm{L}$. & $\mathrm{R}$ & $\mathrm{R}$ & 7 & $\begin{array}{l}12.5 \\
0\end{array}$ & $\mathrm{D}$ & $\begin{array}{l}\text { Introduced palm } \\
\text { tree }\end{array}$ \\
\hline 2. Nypa fruticans Wurmb. & $\mathrm{Vr}$ & $\mathrm{Vr}$ & 5 & 5,00 & $\mathrm{C}$ & $\begin{array}{l}\text { Indigenous palm } \\
\text { tree }\end{array}$ \\
\hline \multicolumn{7}{|l|}{ 4. COMMELINACEAE (1/1) } \\
\hline 1. Zebrina pendula Achnize & $\mathrm{R}$ & $\mathrm{R}$ & 6 & 10 & $\mathrm{C}$ & Introduced herb \\
\hline \multicolumn{7}{|l|}{ 5. ORCHIDACEAE (2/2) } \\
\hline 1. Bulbophyllum sp. & $\mathrm{R}$ & $\mathrm{R}$ & $\begin{array}{l}1 \\
2\end{array}$ & 7,50 & A & Indigenous herb \\
\hline 2. Dendrobium sp. & $\mathrm{R}$ & $\mathrm{R}$ & $\begin{array}{l}1 \\
0\end{array}$ & 7.50 & A & Indigenous herb \\
\hline
\end{tabular}

6. POACEAE (1/1)

1. Stenotaphrum micranthum $\mathrm{R}$ (Desv.) C.E. Hubb

$\mathrm{R}$

$5 \quad 12.5 \quad \mathrm{D} \quad$ Introduced grass

7. TACCACEAE (1/1)

1. Tacca leontopetaloides (L.) $\mathrm{R}$

$\mathrm{R}$ 0

O.Ktze

8. ZINGIBERACEAE (2/2)

1. Alpinia sp.

$\mathrm{R}$

$\mathrm{R}$

$\begin{array}{lll}7 & 17.5 & \mathrm{D}\end{array}$

Indigenous herb, medicinal 
Malaysian Journal of Science 35 (2): 192 - 212 (2016)

2. Costus specious (Koen.) Sm. $\quad \mathrm{R}$

$\mathrm{R}$

$5 \quad 12.5 \quad \mathrm{D}$

Indigenous herb, medicinal

III. DICOTYLEDONEAE

families)

1. ACANTHACEAE (4/4)

1. Acanthus ilicifolius L. $\quad \mathrm{Vr}$

0

2. Andrographis paniculata $\mathrm{R}$ (Burm.f) Ness

3. Asystasia nemorum Nees

$\mathrm{R}$

4. Barleria prionitis L.

$\mathrm{R}$

$\mathrm{R}$

$\mathrm{R}$

$\mathrm{R}$

\section{ANACARDIACEAE (4/6)} (Houtt.)Merr.

2. Mangifera indica $\mathrm{L}$.

$\mathrm{R}$

Mangifera indica L.

$\mathrm{R}$

$\mathrm{R}$

3. Semecarpus venenosus Volk.

4. Spondias dulcis Soland.ex Park

$\mathrm{R}$

$\mathrm{R}$

5. S. mombin L.

VR

6. S.pinnata (L.f) Kurz

$\mathrm{R}$

\section{APOCYNACEAE (4/4)}

1. Allamanda catharthica L.

$\mathrm{R}$

2. Nerium oleander L.

$\mathrm{R}$

3. Plumeria sp.

$\mathrm{R}$

4. Urceola sp.

$\mathrm{R}$

$\mathrm{R}$

$\mathrm{R}$

$\mathrm{R}$

$?$

\section{ARALIACEAE (1/1)}

1. Polyscias grandifolia Volk.

$\mathrm{R}$

5. ASCLEPIADACEAE (5/5)

1. Asclepias curassavica L.

2. Dregea volubilis (L.f.) Bth.ex

$\mathrm{R}$

Hook.f

3. Gymnanthera paludosa $\mathrm{R}$

(B1.)K.Schum

4. Hoya diversifolia $\mathrm{B} 1$.

5. Ischnostema carnosum $\mathrm{R}$ (Schltr.)Merr. \& Rolf.

$6 . \quad$ ASTERACEAE

(COMPOSITAE) $(3 / 3)$

1. Eleutheranthera ruderalis $\mathrm{R}$ (SW.) Schip.- Bip.

2. Synedrella nodiflora (L.) R Gaertn.

$\mathrm{R}$
$\mathrm{Vr}$

$\begin{array}{ccccc}\mathrm{Vr} & 3 & 5.00 & \mathrm{C} & \begin{array}{c}\text { Indigenous } \\ \text { mangrove herb } \\ \mathrm{R}\end{array} \\ & 5 & 7.50 & \mathrm{C} & \text { Herb } \\ \mathrm{R} & 5 & 7.50 & \mathrm{C} & \text { Herb } \\ \mathrm{R} & 5 & 5.50 & \mathrm{C} & \text { Herb }\end{array}$

$\mathrm{R}$

$\mathrm{Vr}$

$\mathrm{Vr}$

VR

$\mathrm{Vr}$

$\begin{array}{lll}1 & 12.5 & \mathrm{~B} \\ 0 & 0 & \\ 7 & 7.50 & \mathrm{C} \\ & & \\ 5 & 7.50 & \mathrm{C} \\ 7 & 7.50 & \mathrm{C} \\ 5 & 7.50 & \mathrm{C} \\ & & \\ 3 & 7.50 & \mathrm{C}\end{array}$

Indigenous tree

Introduced fruit tree, cultivated Introduced tree Introduced fruit tree, cultivated Introduced fruit tree, cultivated Introduced fruit tree, cultivated

Introduced exotic shrub

Introduced exotic shrub

Introduced exotic tree

Indigenous shrub

Introduced

$\begin{array}{lll}8 & 7.50 \quad \mathrm{C}\end{array}$

Indigenous Indigenous

Indigenous

Indigenous, medicinal plant Indigenous

Indigenous

Indigenous weed 
Malaysian Journal of Science 35 (2): 192 - 212 (2016)

$\begin{array}{lll}5 & 5.00 \quad \mathrm{C}\end{array}$

Indigenous

7. BORRAGINACEAE (1/1)

1. Cordia subcordata Lamk.

$\mathrm{R}$

$\mathrm{R}$

$7.50 \quad \mathrm{~A}$

Indigenous tree

\section{CACTACEAE $(1 / 1)$}

1. Opuntia vulgaris Mill.

$\mathrm{Vr}$

$\mathrm{Vr}$

$27.50 \quad \mathrm{C}$

Introduced (?)

9. CAPPARACEAE (1/1)

1. Cleome gynandra $\mathrm{L}$.

$\mathrm{R}$

$\mathrm{R}$

$25.00 \quad \mathrm{C}$

Indigenous

10. CHENOPODIACEAE (1/1)

1. Suaeda maritima (L.) Dum.

$\mathrm{R}$

$\mathrm{R}$

$\begin{array}{lll}8 & 12.5 \quad \mathrm{D} \\ & 0\end{array}$

Indigenous

11. COMBRETACEAE $(1 / 1)$

1. Lumnitzera racemosa Willd.

$\mathrm{R}$

$\mathrm{R}$

$25.00 \quad \mathrm{C}$

Mangrove tree

12. CONVOLVULACEAE (1/4)

1. Ipomoea maxima (L.f.) G.Don $\mathrm{R}$ ex Sweet

2. I. trichosperma $\mathrm{Bl}$.

3. I. tuba (Schelchtend.) G.Don

4. I. littoralis B1.

$\mathrm{R}$

13. CRASSULACEAE (1/1)

1. Kalanchoe pinnata (Lamm.) $\mathrm{R}$ Pers.

$\mathrm{R}$

\section{CUCURBITACEAE $(1 / 1)$}

1. Coccinia grandis (L.) Voigt

$\mathrm{R}$

$\mathrm{R}$

7.50

C

Indigenous

15. EUPHORBIACEAE (10/13)

1. Acalypha indica $\mathrm{L}$.

2. Breynia sp.

3. B. laevigata (B1.) MA

4. Codiaeum variegatum (L.) B1.

5. Euphorbia atoto Forst.

6. E. hirta L.

7. Excoecaria agallocha $\mathrm{L}$.

8. Jatropha gossippifolia $\mathrm{Vr}$ var.elegans M.A

9. Macaranga sp.

10. Mallotus philippensis L.

11. Phyllanthus sp.
$\mathrm{R}$

$\mathrm{R}$

$\mathrm{R}$

$\mathrm{R}$

$\mathrm{R}$

$\mathrm{R}$

$\mathrm{Vr}$

$\mathrm{Vr}$

$\mathrm{R}$

$\mathrm{R}$

$\mathrm{R}$
$\mathrm{R}$

$?$

$?$

$\mathrm{R}$

$?$

$?$

$?$

$\mathrm{Vr}$

$\mathrm{R}$

$\mathrm{R}$ 

12. P. virgatus Forst.f
13. Ricinus communis L.
16.
LEGUMINOSAE
(FABACEAE) (13/17)

$\mathrm{R}$

$\mathrm{R}$

1. Abrus precatorius $\mathrm{L}$.

2. Albizia sp.

3. A. lebbeck (L.) Bth.

4. Caesalpinia crista L.

5. C. bonduc L.emend. Dandy \& $\mathrm{R}$ Exill

6. Cassia sp. R

7. Delonix regia (Boj.ex Hook) R

Raf.

8. Derris scandens (Roxb.)Bth. $\quad \mathrm{R}$

9. D. trifoliata Lour. $\quad \mathrm{R}$

10. Desmodium umbellatum $\mathrm{R}$

(L.)DC

11. Erythrina variegata var $\mathrm{R}$ orientalis (L.) Merr.

12. Leucaena leucocephala (Lam.) R de Wit

13. Lysiphyllum binatum (Blanco) R de Wit

14. Pithecelobium dulce $\mathrm{R}$ (Roxb.)Bth.

15. Sesbania grandiflora Pers. R

16. S. sericea (Wild.) Link. $\quad$ R

17. Tamarindus indica $\mathrm{L}$.

$\mathrm{R}$

\section{FLAGELLARIACEAE (1/1)}

1.Flagellaria indica $\mathrm{L}$.

$\mathrm{Vr}$

$?$

18. GOODENIACEAE (1/1)

1. Scaevola taccada Roxb.

$\mathrm{R}$

$\mathrm{R}$

$\mathrm{R}$

$\mathrm{R}$

2. Cratoxylum formosum (Jack.) $\mathrm{R}$

Dyer

20. HERNANDIACEAE (1/1)

1. Hernandia peltata Meissn.

$\mathrm{R}$

$\mathrm{R}$

21. LABIATAE (1/1)

1. Leonitis nepentaefolia (L.)R.Br. $\quad \mathrm{R}$

$\mathrm{R}$

22. LAMIACEAE (1/1)
$\mathrm{R}$

$\mathrm{R}$

$\mathrm{R}$

$\mathrm{R}$

$\mathrm{R}$

$\mathrm{R}$

$\mathrm{Vr}$

$\mathrm{R}$

$\mathrm{R}$

R

$\mathrm{R}$

$\mathrm{R}$

$\mathrm{R}$

$\mathrm{R}$

R

$\mathrm{R}$

$\begin{array}{llll}? & 1 & 12.5 & \mathrm{~B} \\ \mathrm{R} & 2 & 0 & \\ & 4 & 10 & \mathrm{C}\end{array}$

Indigenous weed

Exotic tree
Indigenous

Indigenous ornamental tree Indigenous shrub

Indigenous shrub

Introduced ornamental tree, exotic

Indigenous

Indigenous

Indigenous

Indigenous tree

Introduced tree, planted Indigenous

Introduced, planted Introduced, planted Introduced, planted Introduced, planted

Indigenous

Indigenous shrub Indigenous tree Indigenous tree$$
\text { (n) }
$$ 
1. Ocimum sanctum $\mathrm{L}$.

$\mathrm{R}$

$\mathrm{R}$

23. LAURACEAE $(2 / 2)$

1. Cassytha filiformis L.

2. Persea Americana Mill.

$\mathrm{R}$

$\mathrm{R}$

$\mathrm{R}$

$\mathrm{R}$

24. LECYTHIDACEAE (1/2)

1. Barringtonia asiatica (L.) Kurz. $\quad \mathrm{R}$

2. B. insignis (B1.) Miq.

$\mathrm{Vr}$

$\mathrm{R}$

$\mathrm{Vr}$

25. LOGANIACEAE (1/1)

1. Spigelia altelmia (L.) Kurz.

$\mathrm{R}$

26. LORANTHACEAE (1/1)

1. Viscum ovalifolium Wall.ex DC

$\mathrm{R}$

27. MALPHIGIACEAE (1/1)

1. Hiptage benghalensis (L.) Kurz. R

28. MALVACEAE (2/3)

1. Abutilon indicum var albescens $\mathrm{R}$ (Miq.) Borss.

2. Sida acuta Burm.f

3. S. rhombifolia $\mathrm{L}$.

$\mathrm{R}$

$\mathrm{R}$ $\begin{array}{lll}9 & 17.5 \quad \mathrm{D} \\ & 0 & \end{array}$

Indigenous
Introduced herb Introduced fruit tree, cultivated

$\begin{array}{llll}5 & 7.50 & \mathrm{C} & \text { Introduced herb } \\ 5 & 12.5 & \mathrm{D} & \text { Introduced fruit } \\ & 0 & & \text { tree, cultivated }\end{array}$

$\begin{array}{cccc}5 & 7.50 & \mathrm{C} & \begin{array}{c}\text { Indigenous timber } \\ \text { tree }\end{array} \\ 3 & 5.00 & \mathrm{C} & \text { Indigenous tree }\end{array}$

$35.00 \quad \mathrm{C}$

Indigenous tree

$\begin{array}{lll}1 & 15.0 & \mathrm{~B}\end{array} \quad$ Indigenous weed

$\begin{array}{lll}6 & 7.50 \quad \mathrm{C}\end{array}$

Indigenous (?)

$5 \quad 5.00 \quad \mathrm{C}$

Indigenous

Indigenous

Indigenous

$\begin{array}{lll}7 & 12.5 & \mathrm{D}\end{array}$

0

$\begin{array}{lll}1 & 15.0 \quad \mathrm{~B}\end{array}$

90

Indigenous weed

[27]. MELIACEAE (3/3)

1. Aglaia elaeagnoidea (Juss.) Bth $\quad \mathrm{R}$

$\mathrm{R}$

$\mathrm{R}$

$\begin{array}{lll}6 & 7.50 \quad \mathrm{C}\end{array}$

Indigenous tree Indigenous tree

$\mathrm{Vr}$ 0

$25.00 \quad \mathrm{C}$

Indigenous mangrove tree

M. Roem

30. MENISPERMACEAE (1/1)

1. Cocculus trilobus (Thunb.) DC R

$\mathrm{R}$

$\begin{array}{lll}7 & 12.5 & \mathrm{D} \\ & 0 & \end{array}$

Indigenous

\section{MORINGACEAE (1/1)}

1. Moringa pterygosperma Gaertn. $\mathrm{R}$

$\mathrm{R}$

$\begin{array}{lll}7 & 7.50 \quad \mathrm{C}\end{array}$

Indigenous

32. MYRSINACEAE (1/1)

1. Aegiceras corniculatum (L.) $\mathrm{Vr}$

$\mathrm{Vr}$

$2 \quad 2.50 \quad \mathrm{C}$

Indigenous mangrove tree

33. MORACEAE (3/4) 
1. Artocarpus altilis (Park.)Fosb. $\quad \mathrm{R}$

2. Ficus sp.

3. F. religiosa $\mathrm{L}$.

4. Maclura conchichinensis $\mathrm{R}$ (Lour.) Corner

34. MYRTACEAE (2/3)

1. Eugenia javanica Lam

2. E. laxiflora (B1.) K.AV non $\mathrm{R}$ Poir

3. Decaspermum fruticosum Forst. $\mathrm{R}$

35. NYCTAGINACEAE $(2 / 2)$

1. Boerhavia repens $\mathrm{L}$.

2. Pisonia grandis L.

$\mathrm{R}$

$\mathrm{R}$

36. OXALIDACEAE (1/1)

1. Averrhoa carambola $\mathrm{L}$.

$\mathrm{R}$

$\mathrm{R}$
$\mathrm{Vr}$

$5 \quad 5.00 \quad \mathrm{C}$

$2 \quad 5.00 \quad \mathrm{C}$

Indigenous Indigenous

[36]. PASSIFLORACEAE (1/1)

1. Passiflora sp.

$\mathrm{R}$

$\mathrm{R}$

$\mathrm{R}$

$\mathrm{R}$

$\mathrm{R}$

1. Piper sp.

40. RHIZOPHORACEAE (3/5)

1. Bruguiera cylindrica (L.)Bl. R

2. B. gymnorrhiza (L.)Lamk. R

3. B. parviflora (Roxb.) Wight \& R Arn.

4. Ceriops decandra (Griff.)Ding $\mathrm{R}$ Hou

5. Rhizophora apiculata Bl.

$\mathrm{R}$

\section{RUBIACEAE (6/7)}

1. Guettarda speciosa L.
$\mathrm{R}$

$\mathrm{R}$

$\mathrm{Vr}$

$\mathrm{Vr}$

$\mathrm{R}$

$\mathrm{R}$

$\mathrm{R}$

$4 \quad 5.00 \quad \mathrm{C}$

$\begin{array}{lll}4 & 12.5 & \mathrm{D} \\ & 0 & \end{array}$

$\begin{array}{lll}6 & 12.5 & \mathrm{D}\end{array}$

$3 \quad 12.5 \quad \mathrm{D}$

0

Indigenous

Indigenous

Indigenous ndigenous food tree, exotic Indigenous

Introduced exotic Indigenous
Introduced fruit tree, planted

Indigenous (?)

$\begin{array}{ll}8 & 15 . \\ & 0\end{array}$

$5 \quad 5.00 \quad \mathrm{C}$

Indigenous

Indigenous 
2. Hedyotis corymbosa (L.)Lamk. $\quad \mathrm{R}$

3. H. fruticulosa (Volk.)Merr. $\quad \mathrm{Vr}$

4. Ixora timorensis Decne

$\mathrm{R}$

5. Oldenlandia sp.

6. Padera scandens (Lour.)Merr. $\mathrm{R}$

7. Scyphiphora hydrophyllacea $\mathrm{Vr}$ Gaertn.f

42. RUTACEAE (2/2)

1. Citrus aurantium L.

$\mathrm{R}$

2. Triphasia trifolia (Burm.f) R F.Wills.

\section{SALVADORACEAE (1/1)}

1. Azima sarmentosa (B1.) B.\& H R

$\mathrm{R}$

44. SAPINDACEAE $(4 / 4)$

1. Alectryon serratus Radlk.

\section{$\mathrm{R}$}

2. Arytera litoralis $\mathrm{B} 1$.

$R$

3. Elattostachys verrucosa (B1.) $\mathrm{R}$

Randlk.

4. Schleichera oleosa (Lour.) $\mathrm{R}$ Oken

45. SAPOTACEAE $(2 / 3)$

1. Manilkara kauki (L.)Dubard Vr

2. Mimusops coreiacea (DC.)Miq. $\mathrm{Vr}$

3. M. elengi L.

$\mathrm{Vr}$

46. SOLANACEAE (1/2)

1. Physalis sp.

2. P. minima $\mathrm{L}$.

$\mathrm{R}$

$\mathrm{R}$

47. SONNERATIACEAE $(1 / 1)$

1. Sonneratia ovata Back.

$\mathrm{Vr}$

$\mathrm{Vr}$

$\mathrm{Vr}$

$\mathrm{Vr}$

48. STERCULIACEAE (3/3)

1. Abroma augusta (1.)L.f

2. Heritiera littoralis Ait.

3. Sterculia foetida L.

49. SYMPLOCACEAE (1/1)

1. Symplocos sp.

$\mathrm{Vr}$

$\mathrm{Vr}$

R

$\mathrm{Vr}$

$\mathrm{Vr}$

$\mathrm{Vr}$

$\begin{array}{lll}8 & 7.50 & \mathrm{C} \\ 9 & 7.50 & \mathrm{C}\end{array}$

$\mathrm{R}$

$\mathrm{Vr}$

$35.00 \quad \mathrm{C}$

Mangrove tree

50. UMBELLIFERAE (1/1)

$\begin{array}{lll} & 0 & \\ 6 & 7.50 & \mathrm{C} \\ 5 & 7.50 & \mathrm{C} \\ 4 & 12.5 & \mathrm{D} \\ & 0 & \\ 5 & 5.00 & \mathrm{C} \\ 5 & 7.50 & \mathrm{C} \\ 2 & 5.00 & \mathrm{C}\end{array}$

$4 \quad 12,5 \quad \mathrm{D}$

$5 \quad 7.50 \quad \mathrm{C}$

$\begin{array}{lll}5 & 7.50 \quad \mathrm{C}\end{array}$

Indigenous

Indigenous

Indigenous

Indigenous

Indigenous
Introduced

Introduced 
Malaysian Journal of Science 35 (2): 192 - 212 (2016)

1. Centella asiatica (L.)Ure

$\mathrm{R}$

$\mathrm{R}$

$\begin{array}{lll}1 & 15.0 & \text { B } \\ 2 & 0\end{array}$

Indigenous

51. URTICACEAE (2/3)

1. Laportea sp.

2. L. interrupta (L.) Gaud.

3. Procris sp.

52. VERBENACEAE (2/4)

1. Avicennia alba $\mathrm{Bl}$.

2. A. marina (Forsk.) Vierh.

3. A. officinalis $\mathrm{L}$.

4. Vitex trifolia $\mathrm{L}$.

53. THYMELAEACEAE (1/1)

1. Phaleria sp.

54. TILIACEAE (3/3)

1. Corchorus aestuans L.

2. Triumfetta procumbens Forst.f

3. Zizyphus jujuba Lam.

\section{FERNS (5 families)}

1. MARANTTIACEAE (1/1)

1. Angiopteris sp.

$\mathrm{R}$

$\mathrm{R}$

$\begin{array}{lll}6 & 12.5 & \mathrm{D}\end{array}$

0

2. OPHIOGLOSSACEAE (2/2)

1. Helminthostachys zeylanicum $\mathrm{R}$

Hook.

2. Ophioglossum sp.

\section{PARKERIACEAE (1/1)}

1. Ceratopteris sp.

$\begin{array}{lll}4 & 12.5 & \mathrm{D} \\ & 0\end{array}$

Indigenous

\section{POLYPODIACEAE ((11/11)}

1. Acrostichum aureum $\mathrm{L}$.

2. Adiantum $\mathrm{sp}$.

3. Antrophyum sp.

4. Asplenium nidus $\mathrm{L}$.

5. Blechnum sp.
$\mathrm{R}$

$\mathrm{R}$

$\mathrm{R}$

$\mathrm{R}$

$\mathrm{R}$

$\mathrm{R}$

$\mathrm{R}$

$\mathrm{Vr}$

$\mathrm{R}$

$\mathrm{Vr}$

$\begin{array}{lll}8 & 12.5 & \mathrm{D} \\ & 0 & \\ 8 & 12.5 & \mathrm{D}\end{array}$

0
Indigenous Indigenous (?) Indigenous

Indigenous mangrove tree Indigenous mangrove tree Indigenous mangrove tree Exotic (?)

Indigenous

Indigenous Indigenous Introduced (?)
Indigenous weed (?) Indigenous Indigenous (?)

Indigenous

Indigenous (?), ornament fern Indigenous 


\begin{tabular}{|c|c|c|c|c|c|c|}
\hline 6. Cheilanthes sp. & $\mathrm{R}$ & $\mathrm{R}$ & 4 & $\begin{array}{l}10.0 \\
0\end{array}$ & $\mathrm{D}$ & Indigenous \\
\hline 7. Cyclosorus sp. & $\mathrm{Vr}$ & $\mathrm{Vr}$ & 2 & $\begin{array}{l}10.0 \\
0\end{array}$ & $\mathrm{D}$ & Indigenous \\
\hline 8. Davalia sp. & $\mathrm{R}$ & $\mathrm{R}$ & 4 & $\begin{array}{l}12.5 \\
0\end{array}$ & $\mathrm{D}$ & Indigenous \\
\hline 9. Polypodium sp. & $\mathrm{R}$ & $\mathrm{R}$ & 5 & $\begin{array}{l}12.5 \\
0\end{array}$ & $\mathrm{D}$ & Indigenous \\
\hline 10. Pteris sp. & $\mathrm{R}$ & $\mathrm{R}$ & 5 & $\begin{array}{l}12.5 \\
0\end{array}$ & $\mathrm{D}$ & Indigenous (?) \\
\hline 11. Thelypteris sp. & $\mathrm{R}$ & $\mathrm{R}$ & 7 & $\begin{array}{l}10.0 \\
0\end{array}$ & $\mathrm{D}$ & Indigenous \\
\hline
\end{tabular}

\section{PSILOTACEAE (1/1)}

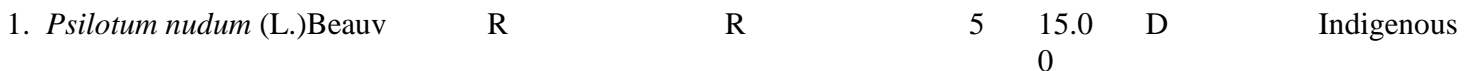

\section{THE STUDY AREA}

Pari Island is a small island, and is part of the buffer zone of SMNP in the Jakarta Bay. The vegetation type of Pari island represent a coral vegetation with variation of mix seashore plant association, coconut plantation and Alang alang (Imperata cylindrica). Approximately 40 $\mathrm{km}$ northwest of Jakarta in Java. The Pari Island is solid-type reefs with a lagoon, on the Sunda continental shelf.

The distance across and area of the Pari Island are about $0.5 \mathrm{~km}$ and $2.5 \mathrm{~km}^{2}$, respectively. Apart from reef-flats, the beaches of Pari Island consist of coarse sand or coral shingle and/or coral fragments, with considerable quantities of humus or other debris in some places. There is no high dune rim.

The islands fall within a relatively small area of low rainfall along the northern coast of West Java. The mean annual rainfall during 1970-2005 was $3,015 \mathrm{~mm}$, with the driest months (less than $50 \mathrm{~mm}$ per month) during July to October and the wettest (more than $100 \mathrm{~mm}$ per month) from December to March [43]. Some parts may in fact receive more rain but accurate documentation is lacking. Rainfall is very irregular, not only in quantity but also in spread over the year. Generally speaking, it is scanty from July till November. During the rainy season, from December to February, the rains come in heavy short-lived showers, which are often of local importance only.
The mean annual temperature on the islands is $27.50^{\circ}$ (1.50) $\mathrm{C}$, with only slight variation in the average daily temperatures [43]. August to October is considered to be the hottest period with an average of $34.10^{\circ} \mathrm{C}$, February as the coolest month with an average of $21.50^{\circ} \mathrm{C}$.

The climate of this region corresponds to the AB types of [48], consequently, the vegetation is wet tropical with marked variation in structure and species composition depending on soil type.

\section{MATERIAL AND MENTHODS}

After revisiting the island after 13 years (2001), 20 years (2005) and 26 years (2011), published check list with annotation on distribution of plants and their present status are [7][26] [27] [22] [55] [23] [21]. The areas and plots surveyed between April 1984 and April 1987 are used for a number of general check-list trips in Pari Island. We visited the islands 3 times on April 2001, April 2005, and December 2011 respectively. During each visit, we make observations on the conditions of the vegetation and its composition, and Table 1 indicate the status, trends and threats to plant population within Pari Island. The nomen calture of all plants in the study area originaly follow the [7].

In the present paper rare species are mostly those which fall into the rare or threatened category used by IUCN [2] [26], but exclude ornamet species. 


\section{RESULTS AND DISCUSSIONS}

\section{Analysis for the plants of Pari Island}

Pari Island of the Jakarta Bay is part of buffer zone of the SMNP, and constitutes to the bio-geographical region of Java and Bali or sub floristic province called West Malesia [59] [62] [27] [10]. The flora (82 families, 315 flowering species, 17 terrestrial fern species) [55] of Pari Island has found also in Java [7] [8], and Anacardiaceae (7 species), Asteraceae (14 species), Convolvulaceae (8 species), Cyperaceae (8 species), Euphorbiaceae (16 species), Leguminosae (28 species), Poaceae (20 species), Rubiaceae (11 species), Solanaceae (7 species), Verbenaceae (8 species) and Polypodiaceae (12 fern species) being the common family. This, however, is not surprising, as plants able to reach Pari Island from Java must have very good dispersal abilities, so the barriers within Pari Island will be of minor influence.

There are 12 most threatened plant families in Malesia [26], and of which 8 families was found in Pari Island along with their rare species viz. Apocynaceae (4 rare species, $80 \%$ ), Euphorbiaceae (13 rare species, $75 \%$ ), Lauraceae (2 rare species, 100\%), Leguminosae (17 rare species, $70 \%$ ), Meliaceae (4 rare species, 100\%), Palmae (2 rare species, 70\%), Sapindaceae (4 rare species, 80\%) and Sapotaceae (3 rare species, 100\%) (Table1). All of plant belong to those families are considered as introduce species. In Pari Island, the plants considered rare being a number of individual less than 10 and frequency of occurrences less than $10 \%$. A total of 174 rare species (14 species of monocotyledon, 144 species of dicotyledonous and 16 fern species) include the species of above 8 families can be identified along with their rarity and 22 rare species or $20 \%$ is indigenous flora (Table 1). The most severely threatened rare species was tree species with only 5 individuals of this species are known. The problem is that 174 plant species regarded as extremely rare in Pari Island may be abundant elsewhere [2]. A local example is the mangrove plants (Aegiceras corniculatum, Avicennia alba, A. officinalis, Bruguiera cylindrica, B. gymnorrhiza, B. parviflora, Ceriops decandra, Heritiera littoralis, Nypa fruticans, Scyphyphora hydrophyllacea, Xylocarpus moluccensis). This mangrove plants is an abundant species in Indonesia and/or Malesia [56] [20] but in Pari
Island is restricted to a small number of sites where it grows adjacent to the edge of coral reef flats. Also, varies used and the threats on e.g., $B$. gymnorrhiza have lead to its IUCN critical endangered status in India in 1997 [40]. We will include to realise then, that rare embraces a range of situations, and need a range of situational criteria [17].

The rare flora (Table 1) is typical of coral vegetation [63] and has species similarity with the coral islands in other part of Indonesia and/or Malesia [7]. Also, Table 1 showed the general weediness of the flora [60] [69]. In most of the enumeration of floristic composition of six vegetation types (Table 2) based on dominant species and density, there is evidence that rare species occurs and the number of rare tree (up to $10 \mathrm{~cm}$ in diameter or more) species being 7 (possibly a few more), e.g., Manilkara kauki (Sapotaceae), Mangifera indica, Spondias dulcis, $S$. mombi and S. pinnata (Anacardiaceae), but those species being planted by the people. This is a pan-tropical fruit tree flora that show promise for improving the quality of life in tropical areas but become very rare (5 trees, Frequency of occurrence less than 10\%) in natural state of Pari Island (Tables 1-2). All are old and decrepit and so far the limited amount of seed produced has proved impossible to germinate and there appears to be no natural regeneration. Mortality of seedlings is high due to surface drought and movement of debris by wind. From the population genetics viewpoint, low densities mean higher probabilities of depleting genetic variations and lower chances of long-term survival [31]. The tree flora of Pari Island that being planted as introduce species, was in danger of extinction [58] [59]. With the exclusion of ruderal weed, Imperata cylindrica, both native and exotic plants, especially e.g. Euphorbia atoto, E. hirta, Ischaemum muticum, Mikania micrantha, Mimosa invisa, M. pigra, M. pudica, Panicum repens, Paspalum vaginatum, Phyllanthus sp., Tridax procumbens, Wedelia biflora, progressively stabilised part of the loose debris in the sandy substrates and competed with the I. cylindrica, and even causing complete suppression. Also, the grasses Imperata cylindrica and Ischaemum muticum, interspersed by Cyperus difformis, Fimbristylis polytrichoides and Carex sp., a sedges species group of the coral shingles, forming a common carpet species over the coast close to pes-caprae formation or inter-tidal zone (ITZ). Two member of the Panicum tribe have remarkable and quite 
different adaptations to sea-shore life, and occur especially on the sandy of pes-caprae formation as prevalent species, viz. Spinifiex littoreus and Thuarea involuta. Salty-moisture regimes influenced weeds present, e.g. Paspalum vaginatum, a salt-tolerant rhizomatous grass. This grass is good for re-vegetating salt- devastated regions and for erosion control [1]. Generally, the dominant genera in the ITZ or on sea level of Pari Island are the same as these seen in other site of coral islands and/or atoll in IndoPacific coasts [19] [15] [16].

Table 2. Vegetation types of Pari Island.

\begin{tabular}{lccccc}
\hline \multicolumn{1}{c}{$\begin{array}{c}\text { Vegetation } \\
\text { type }\end{array}$} & Family & $\begin{array}{c}\text { Floristic composition } \\
\text { Genera }\end{array}$ & Species & $\begin{array}{c}\text { Rare } \\
\text { Species }\end{array}$ & \\
\hline 1. Pes-caprae & 15 & 37 & 46 & 4 & 6 community types with weeds invasion \\
2. Barringtonia & 15 & 20 & 20 & 4 & Weeds invasion taken places at the ground \\
3. Casuarina & 13 & 16 & 17 & 3 & Single stands with weeds invasion \\
4. Mangroves & 14 & 13 & 21 & 20 & Single dominant of $R$. stylosa \\
5. Sukun & 7 & 10 & 13 & 10 & Weed dominant and abundance \\
6. Coconut & 26 & 37 & 58 & 22 & Weed dominant and abundance \\
\hline
\end{tabular}

Throughout Pari Island and the buffer zone areas of SMNP, coastal zone and marine resources are used intensively by people [43] resulting many conflicts between SMNP managers and local populations [45] [49] [70]. Pari Island are inhabited and visited frequently by tourist parties from Pulau Putri and Ancol Marina Jakarta. The visitors had a profound effect on the vegetation of Pari Island, and there are tourist development activities. Grassland and shrub is something to be removed or modified by those activities. These activities contribute to floristic degradation but eventually increasing of weed species (e.g. Lantana camara, Phylanthus niruri) and introduced plants (e.g. Leucaena leucocephala, Sesbania grandiflora, Tamarindus indicus, Ixora timorensis, Hibiscus rosachinensis, Delonix regia) and environmental stress which may be unfavourable to the native plants. They all grow in one extremely small and vulnerable locality. The medicinal palm tree with rare status in Indonesia e.g. Areca catechu [46] [32] are introduced to Pari Island and planted for the local purposes. Due to over- harvesting the plant being rare, (Table 1). Together with a large number of coconut trees, it is interesting to note that Areca catechu growth well in the coconut field, and in spite of increased visitation; apparently weed species have become established and form an important element in the flora of coconut field e.g. Chromolaena odorata, Mikania micrantha and Mimosa invisa. These 3 species also reported to be the most important weed species in coconut plantations in Indonesia [50]. 58 species of the coconut field flora reported from Pari Island by [55] due to land burning activity are changes considerable structurally their abundance, especially 4 species of troublesome weeds (Chromolaena odorata, Imperata cylindrica, Lantana camara, Panicum repens) and 5 species of principal weeds (e.g. Phyllanthus niruri, Borreria sp., Stachytarpheta jamaicensis) after [27] are developed well as major flora. However, the fundamental data and those trends in population size need to be further study indetail. The small species called Passiflora foetida with miniature passion-fruits surrounded by curious much-branched bracts is also a weed, having been introduced as a cover crop. Of the 58 species include P.foetida , 22 species become rare at the present time (Table 2).

Due to illegal cuttings for village housing and firewood of many native trees from Barringtonias stands, the species (e.g. Barringtonia asiatica, Calophyllum inophyllum, Sterculia foetida), are rapidly disappearing over much of Pari Island and become very rare (Table 1). Also, the local commercially significant 
Moraceae are emergent rare trees, Artocarpus altilis. A few were still in occupation, and usually single and large size tree (both in height and diameter, 20-30 $\mathrm{m}$ and 15-35 $\mathrm{cm} \mathrm{DBH}$, respectively). It is found in the interiors of moderately wet to quite wet substrate, and important source for food and timber locally [51]. A seedling of the stands (Artocarpus altilis) often associated with ground cover of vines (Piper spp., P. aduncum), terrestrial ferns and grasses, and make them more prone to extinction [58] [59]. The product of A. altilis fruits is commercialized in short circuit in the Pari Island. Due to illegal cutting, all of the trees species are endangered and some are extinct (Lesser-known timbers: Chisocheton petandrus, Diospyros maritima, Planchonia valida, Planchonella obovata) [51], and may results in de-floristically of the flowering plants in Pari Island e.g., Leguminosae (Table 1).

Like weeds, rare tree species that being seedling in Pari Island and/or Java and Malesia floras in general are frequently occupiers of ephemeral, seral habitats [22] and exist in a peculiar state of tension in relation to their immediate environment [71] [27] [7]. Compared to Pulau Rambut and Pulau Dua [30] [14], the tree rare species in Pari Island (e.g. Rhizophora apiculata, Melia azadarach, Hernandia peltata) would be expected to occur in the outermost fringe of vegetation above the sandy beach, and with narrowed bands and more subtle zonation patterns beginning from the near shore zone and travelling landward e.g., Premna obtusifolia. In the shore zone, Canavalia maritima, Ipomoea pes-caprae, Spinifex littoreus, Sporobulus javensis growing to be more common, and these species are characteristic of the sandy beaches in both Old and New World Tropics [7] [15] [16][47]. Other members of the family Leguminosae are twines, and one of the most important is Derris elliptica, because its roots produce a resinous substance called rotenone which is a valuable insecticide. Also, 16 rare species of terrestrial ferns, mainly Pteris sp. and Psilotum nudum, seen in a few places, and poorly developed compared to Java due to practical control of Alang alang gresses by fire [8]. Acrostichum aureum are rare species in Pari Island even though regarded as a troublesome weed by foresters, because young trees of commercial mangrove species cannot grow in an A. aureum thicket [54]. Sometimes, ferns occur on the lower side of leaning Pandanus tectorius trunks. Moreover, their rarity at the present time probably indicated insular situation [42].

Six ecological groups of plants in the seashore reported by [55] can be distinguished with different rarity of their species composition e.g. halophytes species (Avicennia marina, Sesuvium portulacastrum, Alternanthera sp., Salicornia sp.) and species of cultivated crop and/or exotic plants (Carica papaya, Colocasia esculenta, Catharanthus roseus, Bougainvillea spectabilis). Also, the rare species occurring in areas under influence of salt-spray become endangered (Scaevola taccada, Crinum asiaticum). Species common in the landward side of the interior seashore such as (Sporobulus sp., Tephrosia sp., Suaeda maritima) become abundance.

\section{Threats}

Antrophogenic cycle represent an important factor and the main permanent threats to the vegetation of Pari islands. Even thought the island belong to buffer zone of marine national park, there are several issues can be identity as follow:

\section{Land-use}

Many of the native plants in Pari Island are in very acute danger, with no possibility of re-establishment should likely become extinct. The percentage of this native plant to all rare plants is $85 \%$. Settlements, housing and other human exploitation on the lands presents by far the most serious menace e.g., Calophyllum inophyllum. The exploitation of sand and gravel (both limited resources) in the seashore area threatens a species confined to beaches [52] [49]. Uncontrolled exploitation sand and gravel however, the whole beach flora and many other marine plants will be in serious danger e.g. tree species.

\section{Fire}

Fire is old technique for clearing the vegetation to be converted into agricultural land. The aftermath of a fire may prove equally critical, as common or fire-adapted species will outnumber the survivors of the original rare species. Consequently the original flora at the sites will be loss and/or changes considerable in the process of secondary succession. Although some species seem to be fairly fire-resistant, most of the rare species have suffered considerably e.g., terrestrial ferns. Seed-bank species and only species capable withstand to fire will be appeared and occur successfully in the 
secondary vegetation. Structure and floristic composition will totally different with the original vegetation.

\section{Human population}

The imposition of human influence on the natural conditions creating the different sites must be kept in mind for the various sites described for Pari Island [70]. Assumes that man has disrupted the community pattern and their habitat features of Pari Island, making the flora unstable for their existence. The dense human population and compound with their needed on Pari Island may be quite devastating.

\section{Introduced plants}

Man and plants are closely interconnected in the field of agricultural purposes and/or human being event on simple connection in small sites of Pari island. The relationship established with the living tree crop over generations in domains as varied as religion, social organization, subsistence needs, and commercial relations e.g. garden in rural Java [53]. The Pari environment has also suffered from the introduction of alien plants. There may be as many introduced plants as indigenous, and the number is still growing. Some alien have been introduced as cultivars, others are weedy species introduced unintentionally.

\section{Causes of extinction}

Pari is small island and always in the demand of land for local people, consequently the plants are crucially in the risk position. Land availability plays a capital role in the process of humanosphere in Pari Island. There is no doubt that in the near future Pari Island will lose more rare plants, but we may learn from those that have already disappeared e.g. Diospyros maritima.

\section{Status of the flora and vegetation on Pari Island}

A number of introduced ornamental species have been reported by [55] since they are important for human being. Most of these not only have decorative flowers (e.g., Delonix regia), but serve as shade and/or fruit trees (e.g., Manilkara kauki) or even for some multi purposes in the home gardens [53] (e.g. Areca catechu, Sesbania grandiflora) [32]. Areca catechu, a palm species attributed an anthropomorphic character or origin in legend is generally linked to a large number of economic and social uses. Moreover, some of the ornamental species have adapted so well that they have escape into the coconut field and bush in Pari Island. Other species are planted precisely because they were not originally part of the local flora, e.g., Cordyline fruticosa. Not all ornamentals and fruit trees are growth well and some of which are become rare (Table 1). No or very little study of the ornamental-fruit trees growth has been done. Compared to Pulau Rambut [30] and Pulau Dua [14], the vegetation types of Pari Island are very little studied of their floristic and structure e.g. [55] [5] [6].

The general impression of the flora and vegetation in Pari Island is affected by anthropogenic factor cf. [19]. However, six vegetation types can be identified along with their floristic composition and represent many human interfernces (Table 2). This phenomenon is unusual in the tropics, where vegetation is noted for its rich composition [7] and trees lifeform are dominant [70] [71] [72] [75]. It is difficult, to infer to what extent the original coastal formation included pure stands of this species as this tree has been so over exploited by human e.g., Callophylum inophyllum and Barringtonia asiatica. Only few trees species with less than $10 \mathrm{~cm} \mathrm{DBH}$ and $5 \mathrm{~m}$ height of coastal formation remain in Pari Island e.g., Cordia subcordata, Erythrina orientalis, Hernandia peltata, Hibiscus tiliaceus, Morinda citrifolia, Pongamia pinnata, and Thespesia populnea. The trees of Hibiscus tiliaceus and Erythrina orientalis of the Calophyllum stands/formations are used as boundary markers in gardens and/or rural landuse due to the ease of multiplying them by pole cuttings cf. [38]. Also, $H$. tiliaceus, a desynchronized deciduous tree, has leaves with diverse colorations (green, yellow and orange) at any one time, so that the tree can be seen from a distance at any period of the year. The young leaves of this tree have curative properties; the bark is used to make thongs and rope; the leaves are frequently used as food wrappers. Finally, all tree species with low local densities constitute a complex situation.

The most important tree component of such vegetation was coconut tree (Cocos nucifera), and occurs widespread throughout the island. Coconut stands is left untended for a long-time and some of the coconut varieties still persist from former plantings. The vegetation of the most Pari Island is replaced predominantly by coconut groves; make only an imperfect 
reconstruction of the original vegetation, even on a generalized level may difficult to identify [55]. Only the most extreme sites (mangroves, sand of calcareous rock or of coral shingles substrates) exclusively support a few characteristic species e.g., Pemphis acidula.

The vegetation types (Table 2) occupy a proper habitat, especially pes-caprae in the sandy habitat, Barringtonia, Casuarina in the sandy beach of supraintertidal area and mangrove formations at the sand beaches, beach ridge and flats of intertidal area. The community was indicated as beach vegetation, and an herbaceous strand vegetation become common [47] and are always supra littoral in Pari Island cf. [33] [65]. The width of the community is not very great, being only a few meters. Thus, the vegetation was difficult to differentiate from the former, due to human alteration. Only scattering saplings on the bare ground can be found e.g., Kleinhovia hospita, Guettarda speciosa, Allophyllus cobbe. Nevertheless, they are important as remnants of formerly more abundant such woodland forest, and as objects for public education. Based on the re-inventory from species present in the few remaining relatively unaltered fragment, rare species occurs (Tables 1-2). The vegetation is known as strand shrub associes and has a simple structure.

It is apparent that the habitats of individual mangrove species on the Pari Island is sandy coral single and, are not equivalent to their habitat in Java-Bali bio-region, allowing for differences in development (Table 3). The main factor controlling the mangrove species and/or individual species in Pari Island appears to be the availability of suitable habitats. Though adapted to such extreme conditions without input of freshwater, the mangrove species are very sensitive to changes in salinity, acidity, or water supply cf. [12] [18] [76]. They represent a fragile habitat easily upset by human disturbance. It is therefore, the single dominant of Rhizophora stylosa indicated its geographical strategies [44], and interpretation of the other mangrove species as rare can be made based on their low number of sites occupied and low local density, and their rarity can be identified (Tables 1-2) [23].

Table 3. Main habitats of common island mangroves in the Kepulauan Seribu district of the Jakarta Bay.

\begin{tabular}{cl}
\hline Genus & \multicolumn{1}{c}{ Habitat } \\
\hline Avicennia & Exposed low-intertidal shingle or rampart rock \\
Bruguiera & Protected lee or central swamps, below Ceriops \\
Ceriops & Swamp edges, at immediate lee of shingle ridges \\
Exoecaria & Protected high intertidal or low-supratidal sand or shingle sand adjcent to swamps \\
Lumnitzer & High-intertidal or low-supratidal muddy shingle adjacent to swamps \\
$a$ & \\
Rhizophor & Main central genus of closed swamps: lee (lagoon) edge of protected mangals in \\
$a$ & muddy behind ramparts (below Ceriops and Bruguiera) \\
Xylocarpu & Raised dry central swamps \\
s & \\
\hline
\end{tabular}

\section{CONCLUDING REMARKS}

With $\quad 17.504$ islands, and many unexplorite botanically, Indonesia is a home botanical promise of unknown species of plants of different vegetation types (cf. Table 1). An therefore recognized as one of the 17megadiversity countries that collectively claim within their boundaries two-thirds of the earth's biological diversity [39] [36]. However, Pari
Island with 174 species being rare, can be considered as one example of the small island of Indonesia-hotspot areas where biodiversity is under constant threat from over-harvesting, pollution, over-population and poverty.

Pari Island plays a vital role in the social, economic and ecological well being of coastal communities in Kepulauan Seribu district. Human populations on Pari Island and buffer zone areas have traditionally relied on the 
sea for much of their nourishment. Pari Island is subject to rapidly increasing pressures associated with ecotourism development in the SMNP, Jakarta Bay. Review of existing literature e.g. [45] [74] [55] and information from this investigation suggest that vegetation of Pari continue in a state of degradation. There is now growing recognition that sustainable utilization of the plants will require both a fundamental change in traditionally exploitative altitudes and greater coordination of management actions.

The plants of Pari Island have been relatively well inventoried [55]. Floristic collection numbers (Genera, Species and Specimen) indicated that de-floristically of Pari flora during re-visited are still occurs. Undoubtedly, the greatest threats to native plants are also common. We re-visited was sufficient to make a detailed noted of the rare plants collected from Pari Island. Major credit for the rare status of plants goes to human factor cf. [59].

The natural ecosystem of Pari Island plays an important role in supporting human activities e.g., collecting edible mantis shrimp [58]. Pari is a small island in which loss of the flora-vegetation and human activities are closely related cf. [41]. The rare plants in Pari Island (Table 1) documented the effects of human interferences activities and support the establishment of conservation plans and strategies to preserve the flora and vegetation of SMNP (BAPPENAS 2003, [10] [11]. Table 1 also proved the difficult towards the protection of plant species in particular site of Pari Island [59]. There is probably no simple answer to the problem: how to minimize man's impact on rare and depleted plants while allowing the genuinely interested person access to Pari Island where they occur. They are still seldom explicitly recognized as such assets in environmental management, despite the fact that their continuous support is a prerequisite for economic activity cf. [4]. But knowledge and sympathy are much more likely to prevent deleterious habitat change caused by people than are rules and penalties. We noted the historical blunders in Pari Island land-use.

In accordance with the Convention on Biological Diversity, rare plants of Pari Island are management issues of SMNP, and within anthropometric ecosystem (used by people). Since the adoption of the Rio Convention on Biological Diversity by GOI (Government of Indonesia), intensified research and/or botanical exploration efforts to document biological diversity are needed [10] [74]. Despite increasing interest in the study of biodiversity of SMNP, information on their small island ecosystems are limited, incomplete and widespread. In other hand, large scale development for tourism activities in the region has been increased. The marine sectors includes small island ecosystems, is now officially a key element in Indonesia's present and future economic development, especially for the ecotourism sector. With 174 rare species, coastal ecosystem and its associated marine biological diversity, Pari Island represents a national treasure (Table 1). It is means there is some need to conserve the island through strengthened the Marine Research Station capability (MRS-LIPI). The MRS-LIPI would be an organization for effective Jakarta Bay Integrated Small Islands Management for SMNP. The baseline information on Pari Island flora was basic requirement for a road map for attaining Zero Biodiversity Loss (ZBL) in the SMNP cf. [3]. The process of establishing effective ZBL in the SMNP reached an important milestone for MRS-LIPI. A better orientation of the discourse and objectives of conservation could probably improve relations between local people and SMNP managers.

Pari Island ecosystem is better represented in their flora [55]. The checklist of rare species follow the nomenclature of [7] (Table 1) is reasonably complete, with names brought up to date. The remarks on rare species based on the number of individual (density) and their frequency of occurrences (number of sites occupied) during short term reconnaissance must be regarded as local characters cf. [23] [13] [21]. Such ideas on remarks by species may, therefore, be accepted as educated guessing and as an element for managing the island in terms of tourist spots. Table 1 to the best of my knowledge, very little rare species in Pari Island are endangered in other part of Indonesia (e.g., Areca catechu, Manilkara kauki), or likely to be considered so, or even threatened species in Java-Bali bio-region cf. [34]. Most of the apparent effects of the listed human activities are changes in the characters of both floras and the vegetation types (Table 2). The trees with less than $10 \mathrm{~cm} \mathrm{dbh}$ and/or the rare status of species (Table 1), and un-complete of their forest reconstruction profile suggests clearly some factors in the environment are play a role principally in the secondary succession e.g., Macaranga sp., Mallotus philippensis cf. [66].

The six vegetation types of Pari Island still contain most of the indigenous species 
belonging to strand flora. Of which most plants provide food, materials for medicines, shelter and clothing, and host of other products of value to people [25] [32]. There is no clear break between food and medicine such as Carica papaya, Citrus aurantium, Persea americana and Tamarindus indica being used in both food and medicine. A change in emphasis is needed, with far more effort on edible and/or wild plants used by people in Pari Island, whether or not these plants enter the monetary economy. No much information is available on useable species of the islands. The only one that is documented to any extent is Pemphis acidula, a medicinal plant [68] [24]. So the understanding of native and/or rare plants in the vegetation dynamics on the Pari Island is based principally on their population density and their occurrences through vegetation analysis. The proportions of the rare species present in the sample plots have undoubtedly changed out with no records of previous species composition. We need to realise then, that rare embraces a range of situations. Most noticeable, is in Pari island, of all human effects is the abundance and composition of the exotic plants or weed vegetation [69]. One of the most abundant and troublesome weeds. After [27] of the Pari island landscape is Imperata cylindrica, a hot plants [4] and usefulness weed as roof thatching, medicinal and beverage [50]. Several weedy Panicum repens are also unusually abundant. Even weed pressure is often negligible; Pari Island vegetation may often be marked by an absence of inter-plant competition. Consequently, human interference on Pari Island and/or buffer zone may be quite devastating cf. [11]. For instance, species of the cultivated as crop (Carica papaya, Colocasia esculenta) and exotic plants (Bougainvillea spectabilis) become common in the home gardens [53].

The native rare tree species in Pari Island are evidently the most vulnerable, and most worthy of protection. Peoples should enjoy special care and priority in conservation and management plans, e.g. for sukun, Artocarpus altilis, an economically and socially valuable Moraceous tree food crop. Also, wild relative of important rare fruit crops of Anacardious, e.g. Spondias dulcis, S. mombin, S. pinnata and Magifera indica is not adequately conserved in existing Pari Island, but further field surveys are needed, also in other islands in the Jakarta Bay, to get an overview of the situation, especially regarding their spatial distribution and abundance as core species [23] [21], and such must be continuously protected and sustainable managed [51].

The above remarks is considered our opinion for understanding the relationship of plant species and human in the contact of conservation and management of small island. In theline of Indonesian Biodiversity Stategy and Action Plan (IBSAP) [10].

The present state of knowledge on Pari flora is still insufficient to conduct a comprehensive plant geographical and/or vegetation analysis of small islands at SMNP of which species still exist cf. [9]. This leads naturally to questions of enhanced legislation for the better protection of endangered species in SMNP.

\section{REFERENCES}

1. Anonymous, (1975). Underexploited tropical plants with promising economic value, 186 pp, National Academic of Sciences: Washington DC.

2. Anonymous, (1980). How to use the IUCN Red data book categories, Gland 1-9: IUCN.

3. Anonymous, (1995). National biodiversity planning: Guidelines based on early experiences around the world, $161 \mathrm{pp}$ : IUCN.

4. Aumeeruddy, Y. (1994). Local representations and management of agroforests on the periphery of Kerinci Seblat National Park, Sumatra Indonesia.

5. Azkab, M.H \& S. Sukardjo. (1987). Komunitas semai hutan mangrove di Pulau Pari, Kepulauan Seribu. In: I. Soerianagara, S. Soemodihardjo (eds.), Prosiding Seminar III Ekosistem Mangrove, LIPI Panitia Nasional Program MAB Indonesia, 1987, pp. 98-109, Jakarta.

6. Azkab, M.H., S. Sukardjo \& A.V. Toro. (1988). Studi fenologi vegetatif mangrove di ekosistem terumbu karang: 2. Morfologi semai Rhizophora stylosa Griff di rataan terumbu karang Pulau Pari. In: M.K. Moosa, D. Praseno (eds.), Teluk Jakarta, 71-78. Puslitbang Oseanologi LIPI, 1988, Jakarta.

7. Backer, C.A \& R.C. Bakhuizen van den Brink, Jr. (1963-1968). Flora of Java Vol. I-III. Noordhoff: Groningen.

8. Backer, C.A \& O. Posthumus. (1939). Varenflora voor Java. Uitgave van's Lands Plantentuin, Buitenzorg, 370 pp, Java.

9. Balgooy, M.M. van. (1987). A plant geographical analysis of Sulawesi. In: T.C.Whitmore (ed.), Biographical evolution 
of the Malay Archipelago, 94-102, Claredon Press: Oxford.

10. BAPPENAS. (2003). Indonesian Biodiversity Strategy and Action Plan 2003-2020. The GOI. 3 vols.

11. Battisse, M. (1982). The biosphere reserve: a tool for environmental conservation and management. Environmental Conservation 9:101-110.

12. Bird, E.C.F. (1993). Submerging coasts: The effects of a rising sea level on coastal environment. Chichester: Wiley.

13. Brown, R. J.H. (1984). On the relationship between abundance and distribution of species. American Naturalist 125:255-279.

14. Buadi. (1979). Hutan bakau di Pulau Dua (Teluk Banten Jawa Barat). In: S. Soemodihardjo, A. Nontji \& A. Djamali (eds.), Prosiding Seminar Ekosistem Hutan Mangrove, 69-71: LIPI Panitia Nasional Program MAB Indonesia, Jakarta.

15. Chapman, V.J. (1944). Cambridge University expedition of Jamaica: 1. A study of the botanical processes concerned in the development of the Jamaica shoreline. J. Linn. Soc. Bot. 2: 407-486.

16. Chapman, V.J. (1978). Coastal vegetation. Second Edition. 292 pp: Pergamon Press Ltd.

17. Dumond, D.M. (1973). A guide for the selection of rare, unique and endangered plants. Castanea 38:387-395.

18. Fosberg, F.R. (1961). Vegetation-free zone on dry mangrove coast. U.S Geological Survey-Profesional Paper 424D: 216-218.

19. Fosberg, F.R. (1976). Coral island vegetation. In: Biology and Geology of Coral Feefs, Vol. III. Biology 2: 255-277 pp: Academic Press INC.

20. Giesen, W. S. Wulffrat, M. Zieren \& L. Scholten. (2006). Mangrove guidebook for Southeast Asia. FAO, Bangkok. 769 pp.

21. Gotteli, N.J \& D.E. Simberloff. (1987). The distribution and abundance of tall grass prairie plants: a test of the coresatellite hypothesis. Amercican Naturalist 130:18-35.

22. Griggs, R.F. (1940). The ecology of rare plants. Bull. Torrey Botanical Club 67:575-594

23. Hanski, I. I. (1982). Dynamics of regional distribution: the core and satellite species hypothesis. Oikos 38:210-221.
24. Hardjito, L. (2007). Antibacterial, antioxidant and topoisomerase-1 inhibitor activities of the coastal ethnomedicinal plant Pemphis acidula. Biotropia 14(2):4351.

25. Heyne, K. (1927). De buttige planten van Nederlands-Indie. Departement van Landbouw, Nejverheid en Handel in Nederlands-Indie. 1953 pp.

26. Hilton-Taylor, C. (2000). IUCN Red list of threatened species. IUCN Gland, Switzerland and Cambridge, UK. xviii + $61 \mathrm{pp}$.

27. Holm, L.G., D.L. Plucknett, J.V. Pancho \& J.P. Herberger. (1977). The world's worst weeds. 609 pp, University Press of Hawaii: Honolulu.

28. Hoogerwerf, A \& G.F.H.W.R.H. Siccama. (1938). De Avifauna van Batavia en omstreken. 243 pp, Leiden E.J. Brill.

29. Jacobs, M. (1974). Botanical panorama of the Malesian archipelago (vascular plants). In: National Resources of Humid Tropical Asia (Natural Resources XII): 262-294. UNESCO.

30. Kartawinata, K \& E.B. Waluyo. (1977). A preliminary study of the mangrove forest on Pulau Rambut, Jakarta Bay. Marine Research in Indonesia 18: 119-129.

31. Lande, R \& G.F. Barrowclough. (1987). Effective population size, genetic variation and their use in population management. In: M.E. Soule (ed.), Viable populations for conservation. 87-123 pp, Cambridge University Press, Cambridge: UK.

32. Lemmens, R.H.M.J \& N. W. Sutjipto. (1991). Plant resources of South-east Asia No.3: Dye and tannin-producing plants. $195 \mathrm{pp}$, Pudoc: Wageningen.

33. Lewis, J.R. (1964). The ecology of rocky shores. English Universities Press: London.

34. Lucas, G. \& H. Synge. (1978). The IUCN plant red data book. IUCN: Switzerland.

35. Meijaard, E., D. Sheil, R. Nasi, D. Augeri, B. Rosenbaum, D. Iskandar, T. Setyawati, M. Lammertink, I. Rachmatika, A. Wong, T. Soehartono, S. Stanley \& T. O'Brien. (2005). Life after logging: reconciling wildlife conservation and production forestry in Indonesian Borneo. $345 \mathrm{pp}$, CIFOR and UNESCO.

36. Mittermeier, R.A., P.R. Gil \& C.G. Mittermeier. (1997). Megadiversity, earth's biologically wealthiest nations. 501 pp, CEMEX, Monterrey: Mexico. 
37. Mittermeier, R.A., C.G. Mittermeier \& N. Myers. (1999). Hotspots: earth's biologically richest and most endangered terrestrial ecoregions. $\mathrm{CI}$ and CEMEX. Mexico City.

38. Muthoo, M.K \& M.E. Chipeta. (1991). Trees and forests in rural land use. . 230 pp, FAO: Rome

39. Myers, N., R.A. Mittermeier, C.G. Mittermeier, G.A.B. Dacosta \& J. Kent. (2000). Hotspots: earth's biologically richest and most endangered terrestrial ecoregions. Nature 403, pp 853-858.

40. Naskar, K \& R. Mandal. (1999). Ecology and biodiversity of Indian mangroves. Daya Publishing House: New Dehli.

41. Odum, E.P. (1989). Ecology and our endangered life-support system. Sinauere Associates, Sunderland: Massachuset.

42. Porter, D.M. (1983). Vascular plants of the Galapagos: origin and dispersal. In: R.J. Bowmann, M. Berson \& A.E. Leviton (eds.), Patterns of evolution in Galapagos organisms, pp 33-96, Pacific Division, AAAS: San Franscisco.

43. Rais, S., Y. Ruhiat, A. Sartono \& T. Hideta. (2007). 50 Taman Nasional di Indonesia. 291 pp, MOF-LHI-JICA.

44. Rapoport, E.H. (1982). Areography: geographical strategies of species. Pergamon, Oxford: England.

45. Salm, R. V \& J.R. Clark. (1984). Marine and coastal protected areas: a guide for planners and managers. $302 \mathrm{pp}$. IUCN.

46. Sangat, H.M., E.A.M. Zuhud \& E.K. Damayanti. (2000). Kamus penyakit dan tumbuhan obat Indonesia. Yayasan Obor Indonesia, Jakarta.

47. Schimper, A.F.W. (1891). Die-Indo-Malayische strand flora. Bot. Mitt. Trop. Jena 3, 204 pp.

48. Schmidt, F.H \& J.H.A. Ferguson. (1951). Rainfall types based on wet and dry period ratios of Indonesia with western New Guinea. Kementrian Perhubungan, Jawatan Meteorologi dan Geofisik. Verhandelingen, 42.

49. Snedaker, S.C \& C.D. Getter. (1985). Coastal resources management guidelines. Coastal Management Publication No.2 US Department of the Interior, $205 \mathrm{pp}$, Washington: DC.

50. Soerjani, M., M. Sundaru \& C. Anwar. (1986). Present status of weed problems and their control in Indonesia. Biotrop Special Publication, 24: 7-23.

51. Sosef, M.S.F., L.T. Hong \& S. Prawiroatmodjo. (1998). Timber trees: Lesser-known timber.
Plant resources of South-east Asia No. 5 (3), 854 pp, Backhuys Publisher: Leiden.

52. Soysa, C.H., C.L. Sien \& W.L. Collier. (1982). Man, land and sea: coastal resource use and management in Asia and the Pacific. 320 pp, The ADC Bangkok.

53. Stoler, A. (1978). Garden use and household economy in rural Java. Bulletine of Indonesian Economic Studies 14(2): 85-101.

54. Sukardjo, S. (1987). Natural regeneration status of commercial mangrove species (Rhizophora apiculata Bl. and Bruguiera gymnorrhiza (L). Lmk.) in the mangrove forest of Tanjung Bungin, Banyuasin district, South Sumatra. Forest Ecology and Management 20:233-252.

55. Sukardjo, S. (2006). Botanical exploration in small islands: 1. Floristic ecology and the vegetation types of Pari Island, West Java, Indonesia. South Pacific Studies 26(2):73100.

56. Sukardjo, S. (2008). Biodiversity and ecological conservation of mangroves in Indonesian South China Sea areas: a botanical exploration of mangrove ecosystems. Paper presented at the South China Sea: Sustaining Ocean Productivities, Maritime Communities and the Climate. Kuantan Malaysia 25-29 November 2008, 24 pp.

57. Sukardjo, S., M.H. Azkab \& A.V. Toro. (1987). Phenological studies of mangroves associated with coral reef ecosystem: Vegetative phenology and growth of Rhizophora stylosa Griff. seedling in the coral reef flat of the Pari island. Biotrop Special Publication, 29: 39-57.

58. Terborgh, J. 1974. Preservation of natural diversity: the problem of extinction prone species. Bioscience 24:715-722.

59. Terborgh, J \& B. Winter. (1980). Some causes of extinction. In: M.E. Saule \& B.A. Wilcox (eds), Conservation biology: an evolutionary-ecological perspective, Sinauer, Sunderland, Massachusetts, pp 119-133.

60. van der Werff, H. (1983). Species number, area and habitat diversity in Galapagos Islands. Vegetatio 54:167-175.

61. van Steenis, C.G.G.J. (1950a). The delimination of Malaysia and its main plant geographical devisions. Flora Malesiana Serie I (1): LXXVI-CXII.

62. van Steenis, C.G.G.J. (1950b). Desiderata for future exploration. Flora Malesiana Serie I (1):CVII-CXVI. 
63. van Steenis, C.G.G.J. (1957). Outline of vegetation type in Indonesia and some adjacent regions. Proceeding of the Pacific Sciences Congress 8(4): 61-97.

64. van Steenis, C.G.G.J. (1958a). Vegetation map of Malesia, scale 1:5,000,000. UNESCO Paris.

65. van Steenis, C.G.G.J. (1958b). Discrimination of tropical shore formation. Proceeding of the Symposium on Humid Tropics Vegetation, Kandy, 215-217. UNESCO, Paris.

66. van Steenis, C.G.G.J. (1958c). Rejuvenation as a factor for judging the status of vegetation types: The biological nomad theory. Proceeding of the Symposium on Humid Tropics Vegetation, Kandy, 218-221. UNESCO: Paris.

67. van Steenis, C.G.G.J. (1972). Enige historische aantekeningen over Flora Malesiana en de betekenis van dit werk voor de bijzondere plantkunde, special met betrekking tot het Rijksherbarium. In: Overdenkingen 47-56. Unive. Press. Leiden.

68. van Steenis, C.G.G.J and M.J. Kruseman. (1953). Select Indonesian medicinal plant. Org. Sc. Res. Indo. Bull. 18:1-90.

69. Veldkamp, J.F. (2001). Weeds: plant for the future. Malayan Nature Journal 55 (12):187-196.
70. Wells, M., K. Brandon \& L. Hannah. (1992). Peoples and parks: linking protected area management with local communities. Washington DC, International Bank for Reconstruction and Development/World Bank. 99 pp.

71. Whitmore, T.C. (1972). Tree flora of Malaya. Vol. 1:237-304 Longman, Kuala Lumpur.

72. Whitmore, T.C. (1990). An introduction to tropical rainforests, $226 \mathrm{pp}$, Oxford University Press.

73. Whitmore, T.C., I.G.M. Tantra \& U. Sutisna. (1986-1990). Tree flora of Indonesia. FRDC, Bogor. 6 vols.

74. Wind, J. \& H.T.T. Prins. (1989). National buffer zone and research management: inception report. $39 \mathrm{pp}$, Bogor, Indonesia, World Bank National Parks Development Project, DHV-RIN Consultancies.

75. Woodreffe, C.D. (1982). Geomorphology and development of mangrove swamps, Grand Cayman, West Indies. Bull. Mar. Sci. 32: 381-198.

76. Woodreffe, C.D. (1983). The development of mangrove from a geological perspective. In: H.J. Teas (ed.), Biology and Ecology of Mangroves, 1-17. Dr. W. Junk, The Hague, Netherlands 